Original Research Paper

\title{
Abiotic Stress Elicitation on Secondary Metabolites of Red Betel (Piper crocatum Ruiz and Pav.) Leaves as Potential Repellent for Rice Bug (Leptocorisa oratorius (F.)
}

\author{
${ }^{1,2}$ Intani Quarta Lailaty, ${ }^{2}$ Diah Rachmawati and ${ }^{2}$ Laurentius Hartanto Nugroho \\ ${ }^{1}$ Cibodas Botanic Gardens-Research Center for Plant Conservation and Botanic Gardens, \\ Indonesian Institute of Sciences, Cianjur, West Java, Indonesia \\ ${ }^{2}$ Faculty of Biology, Universitas Gadjah Mada, Sleman, D.I Yogyakarta, Indonesia
}

\author{
Article history \\ Received: $20-10-2020$ \\ Revised: 23-12-2020 \\ Accepted: 22-01-2021 \\ Corresponding Author: \\ Intani Quarta Lailaty \\ Cibodas Botanic Gardens- \\ Research Center for Plant \\ Conservation and Botanic \\ Gardens, Indonesian Institute \\ of Sciences, Cianjur, West \\ Java, Indonesia \\ Email: intaniquarta@yahoo.com, \\ intani.quarta.lailaty@lipi.go.id
}

\begin{abstract}
Rice bug, Leptocorisa oratorius (F.), is the main pest of rice plants which can reduce rice productivity significantly. Natural insecticide from plant extract compounds, such as Red Betel (Piper crocatum Ruiz and Pav.), is an alternative to reduce the attack of these pests and environmental friendly. This research aimed to study the effect of abiotic stress on plant growth and secondary metabolites profiles of $P$. crocatum leaves that have potential compounds as an insecticide. The research design used a split-split plot design with three factors, namely drought stress 100, 50 and 25\% Field Capacity (FC) light treatment (without shade, shade net $65 \%$ and shade net $75 \%$ ) and fertilizer application (guano and NPK). Data analysis used ANOVA and Duncan Multiple Range Test (DMRT) for growth data, also GC-MS test for profile metabolites analysis. The research showed that the combination of $100 \% \mathrm{FC}$, guano and without shade (W1F1L1) treatment produced the best plant growth. The combination of 50\% FC, NPK and without shade (W2F2L1) had the highest potential to increase the type of insecticide compounds, while the treatment of $100 \%$ FC, NPK and shade net $75 \%$ (W1F2L3) produced the highest insecticide total compounds. There were 32 types of compounds potentially acted as an insecticide in the red betel leaf chloroform extracts. The compound groups covered terpene, monoterpene, sesquiterpene, diterpene and others. The combination of abiotic stress in the form of drought stress, light treatment and fertilizer application affected the growth of $P$. crocatum in terms of plant morphology and biomass. It also could increased the type and content of bioactive compounds in leaves of $P$. crocatum. The W2F2L1 was the best treatment to increase the type of insecticide compounds and the growths of red betel.
\end{abstract}

Keywords: Abiotic Stress, Repellent, Bioprospection, Leptocorisa oratorius (F.), Piper crocatum Ruiz and Pav

\section{Introduction}

Rice bug, Leptocorisa oratorius (F.), is the main insect that attacks rice plants. It has high mobility and can be found on many paddy fields, especially in the rainy season. Weed is an alternative host for rice bugs that usually appear at the end of planting or generative phase (Litsinger, 2009). Rice bug attacks rice plants from flowering until the grain filling stadia. The attack on flowering stadium causes the empty grains, whereas the attacks on grain filling stadia or afterwards results in incompletes grain filling and grain discoloration. In Asia, yield loss due to rice bug ranged from $10-40 \%$ or even almost $100 \%$, while in Indonesia the yield loss ranged from $50-100 \%$ (Litsinger et al., 2015).

The high level of damage due to rice bug attack is a major concern. Controlling rice bugs using pesticides is still considered expensive for farmers and ineffective. In addition, the use of pesticides is feared to disrupt the beneficial insect population around the rice planting area and leave chemical residues in rice. Therefore, some 
alternatives of insecticides which are more effective and environmentally friendly are demanded, one of which is by exploration and optimization of bioactive materials from plants as natural insecticides.

Nugroho et al. (2020) evaluated red betel (Piper crocatum Ruiz and Pav.) has the highest potential for anti-pest control compared to the other four types of Piper. The secondary metabolite compounds were able to control the presence of rice bugs. However, the insecticide compounds from the fraction was not adequate in amount and type of compounds, so efforts are needed to increase the number and levels of secondary metabolites in red betel leaves It has been reported by (Parfati and Windono, 2016), also (Nugroho et al., 2020) that in the red betel extract contained secondary metabolites in the form of flavonoid compounds: Quersetin and auron group compounds; essential oil with components of monoterpenes, sesquiterpenes, alkaloid compounds, tannins-polyphenols, steroids-terpenoids and saponins, which have potential as bioinsecticides.

Secondary metabolites are formed from several processes and can be increased through biotic and abiotic stress treatments. Secondary metabolites could be produced by plants as a response of defense and adaptation to environmental stress (Akula and Ravishankar, 2011; Seigler, 1998). According to (Mazid et al., 2011), drought is a serious threat to agriculture and natural physicalbiochemical properties of plant metabolism. In general, plants show the ability to adopt their metabolism to changes in the environment. Plants synthesize a variety of secondary products with economic value in a normal environment. Research (Muttaleb et al., 2018), the treatment without shade (high light intensity) can increase the accumulation of total phenolic content, total flavonoids and antioxidant activity in Piper betel. In the study of (Sumarwoto et al., 2008) about the red betel planting media derived from a mixture of various types of organic matter had a significant influence on growth (plant height, number of leaves, number of books and length of the first segment).

Increased secondary metabolites to abiotic stress are also shown in various research results, including increases in monoterpenes and essential oils in Salvia officinalis causes drought (Nowak et al., 2010; Bettaieb et al., 2009). Temperature was increased quercetin and kaempferol in Medicago sativa L. (Mølmann et al., 2015), also lights could increased Gingerol and zingiberene in Zingiber officinale (Anasori and Asghari, 2009). Salim et al. (2019) also reported that soil nutrient increased secondary metabolites in Lansium domesticum Corr var Duku. A variety of abiotic stresses, such as drought, light and fertilizer application with specific concentrations is assumed could affect the formation of secondary metabolites. Therefore, in this study, a combination of abiotic stress treatments was carried out to increase secondary metabolites in red betel leaves which are expected to become natural insecticidal compounds, especially for rice bug repellent.

\section{Materials and Methods}

This research used a split-split plot design with three abiotic stress factors, namely drought stress, light treatment and fertilizer application. Each treatment combination consists of five replications.

\section{Plant Growth and Abiotic Stress Treatments}

Drought stress treatment based on field capacity can be determined by the level of water content of each through the method of (Laise et al., 2017) in the planting media of three $\mathrm{kg}$ for each polybag. Drought stress treatment in the form of water level, i.e., $100 \%$ (control), $50 \%$ (moderate) and 25\% (severe) Field Capacity (FC) were given twice for week. The fertilizer application is carried out by adding 25 tons.ha $^{-1}$ of organic guano fertilizer (Yudistira et al., 2018) and $100 \mathrm{~kg} \cdot \mathrm{ha}^{-1}$ of NPK Mutiara 16:16:16 Inorganic fertilizer (Muttaleb et al., 2018) on the plant treatments. Application of fertilizer was added to plants once for a month. The plants are grown in three different light treatment (without shade, shade net covered $65 \%$ and shade net covered $75 \%$ ). Controls were also planted with treatment without shade, $100 \%$ FC and without fertilizer added. Samples are grown for four months. Plant growth and environmental parameters were observed for every week. The observed growth included the number of leaves and plant height was observed every week for 15 weeks. Plant biomass and shoot-root ratio were observed after plant harvest. The measured environmental parameters consist of light intensity, $\mathrm{pH}$ and soil moisture observed once a month. Planting media and guano fertilizer also were analyzed by chemical and physical characteristics. Chemical content analysis, including $\mathrm{pH}$, organic $\mathrm{C}$ content (\%), available $\mathrm{N}$, available $\mathrm{P}$, available $\mathrm{K}$, total extraction of macro and micro nutrient elements and Cation Exchange Capacity (CEC) in the soil. Soil analysis including physical characteristics was conducted at Laboratorium Pengujian, BPPT Yogyakarta.

\section{Secondary Metabolites Profile Analysis}

Preparation of red betel leaves extract using the method of (Yeo et al., 2014) which was modified. $P$. crocatum leaves are cleaned of dirt, dried in an oven at $40^{\circ} \mathrm{C}$ and mashed into powder. Five grams of the powder was put into an Erlenmeyer flask, soaked using $150 \mathrm{~mL}$ of chloroform and covered with aluminum foil for $24 \mathrm{~h}$ while occasionally shaken. After $24 \mathrm{~h}$ the pulp is separated from the filtrate by Whatman No. 1 filter paper. The chloroform filtrate was placed on a porcelain cup and concentrated with a fan. Next, the red betel leaf chloroform extract of each treatment was analyzed for the secondary metabolite profile using GC-MS. 


\section{Statistical Analysis}

The measurement data of growth and environmental parameters were analyzed using descriptive methods and Analysis Of Variance (ANOVA) with the $F$ test at 5\% significance level. Each treatment combination consists of five replications. If the $F$ test has a significant effect, an intermediate test with the Duncan Multiple Range Test (DMRT) is performed at a 5\% significance level. Secondary metabolite profile of $P$. crocatum leaves extract were analyzed using GC-MS. Chromatogram data analyses used WILEY229.LIB, NIST12.LIB and NIST62.LIB databases.

\section{Results}

\section{Plant Growths and Biomass of P. crocatum}

Various types of abiotic stress with specific concentrations affect the formation of secondary metabolites and also has effect to plant growth. In this study, the highest number of leaves was produced by W1F1L1 treatment (100\% FC, guano and without shade), while the fewest leaves were found in W3F1L3 treatment ( $25 \% \mathrm{FC}$, guano and shade net $75 \%$ ). The addition of guano fertilizer resulted in an average number of leaves more than the NPK treatment for several treatment combinations, except for $25 \%$ FC Table 1.

Stem height in all plants with various combinations of abiotic stress treatments increases with increasing planting time each week. Table 1 shows that the W1F1L2 treatment (100\% FC, guano and shade net $65 \%$ ) produced the highest stem at the end of the observation (15 weeks after planting), while the lowest stem height was found in the W3F1L3 treatment $(25 \%$ FC, guano and shade net $75 \%$ ). Based on Table 1, the highest R/S ratio was produced by W1F1L3 treatment ( $100 \%$ FC, guano and shade net $75 \%$ ), while the lowest $\mathrm{R} / \mathrm{S}$ ratio was produced by $\mathrm{W} 3 \mathrm{~F} 1 \mathrm{~L} 3$ treatment combination (25\% FC, guano and shade net $75 \%$ ).

The fertilizer is containing all the micro elements needed by plants. Based on the analysis, Guano fertilizer used in this study contained $0.19 \% \mathrm{P}_{2} \mathrm{O}_{5}$ in the available form was dissolved in water. Guano fertilizer contains less nitrogen than NPK fertilizer, but guano fertilizer has other nutrients. Other macronutrients were contained in guano fertilizer, namely $\mathrm{Mg}$ and $\mathrm{Ca}$. While the micronutrients owned, among others were $\mathrm{Na}, \mathrm{Fe}$ and $\mathrm{Cu}$ Table 2.

From the observations for four months, the range of maximum and minimum light intensities in the treatment group without shade was the highest compared to the other light treatment groups during May to July 2019. However, the range of the highest light intensity was in the group control treatment during August. Meanwhile, the lowest light intensity was in the $75 \%$ shade net treatment group Fig. 1. The availability of water can also affect the moisture and $\mathrm{pH}$ of the growing media. It was shown in the light and drought stress treatment group. The mean $\mathrm{pH}$ of the media in the light treatment group for four months of planting was not different among treatments. Meanwhile, the relative humidity of the media in control plants had the highest value compared to other treatments Fig. 2. The relative humidity of the growing media decreases with the reduction in water received by plants with a treatment of $25 \%$ FC. This is consistent with an increase in the acidity of the media in plants with a treatment of $25 \%$ FC which results in growing media becoming more alkaline Fig. 3.

\section{Secondary Metabolites Profile of P. crocatum}

The research results show that the combination treatment of abiotic stress in the form of drought, light and fertilizer application increased the variation of compounds produced in the leaves of the red betel plant. The control treatment produced 54 types of compounds. The treatment group without shade produced the highest total type of compound compared to those of the other light treatment groups. W2F2L1 treatment $(50 \% \mathrm{FC}$, NPK fertilizer, without shade) produced the most total types of compounds (67 types) after being analyzed using GC-MS. Meanwhile, the W2F2L3 treatment (50\% FC, NPK fertilizer, shade net $75 \%$ ) produced the fewest total compounds, namely 30 types of compounds Table 3. The highest levels of compounds produced in the extract of chloroform red betel leaf treated with various combined abiotic stress treatments, including 2-Carene, 2-Acetyl-(monoterpene), 2-Hydroxy-Beta-Ionone (propane), Phytol (diterpene), 3-Hydroxy-7,8-Dihydro.Beta.-Ionol (phenol) and Delta 3-Carene (monoterpene) are shown in Table 3. Chloroform is the best solvent to showing secondary metabolites of red betel leaves extract, especially for insecticide compounds. It based on previous research from (Nugroho et al., 2020).

From Table 4, 32 types of bioactive compounds are found with different classes. The control treatment produced 11 types of compounds that have the potential as insecticides with a total compound content, which is $3.52 \%$. From the overall results of the analysis, the treatment of W2F1L1, W2F2L1, W2F1L2, W3F2L2 and W1F2L3 produced higher levels and amount of potential insecticide compounds compared to controls. W2F2L1 treatment or T4 (50\% FC, NPK fertilizer, without shade) produced the most potential compound as an insecticide (15 types). Meanwhile, W1F2L3 treatment or T14 ( $100 \%$ FC, NPK fertilizer, shade net $75 \%$ ) produced the highest total levels of insecticide compounds compared to those of other treatments, which was $26.61 \%$, dominated by 3-carene delta compounds (monoterpene), presented in Fig. 4. 


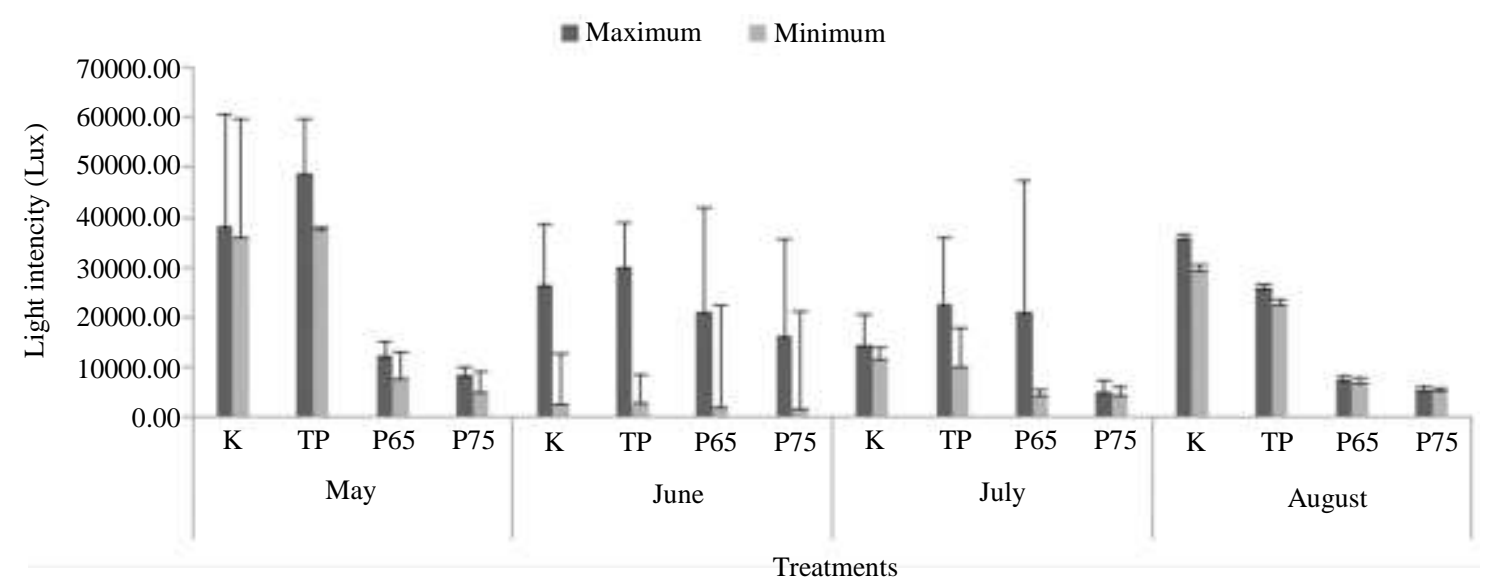

Fig. 1: The maximum and minimum light intensity in a variety of light stress combination treatments. K: Control, TP: Without shade, P65: Shade net $65 \%$, P75: Shade net 75

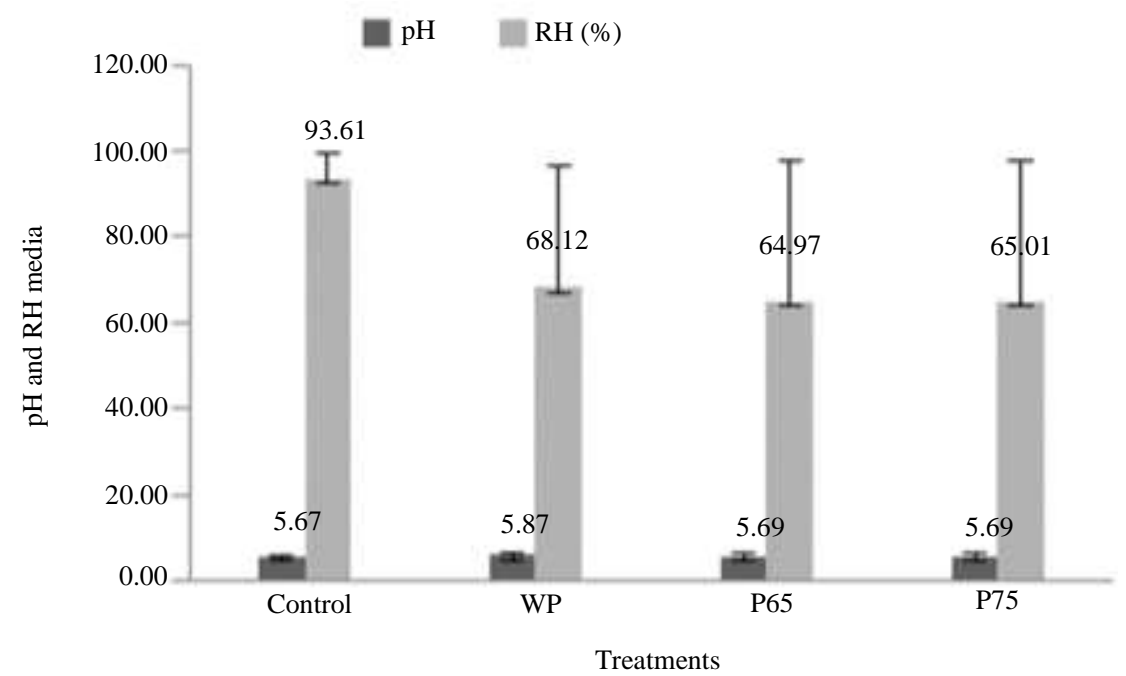

Fig. 2: Relative humidity and $\mathrm{pH}$ of planting media of light treatments. TP: Without shade, P65: Shade net 65\%, P75: Shade net 75\%

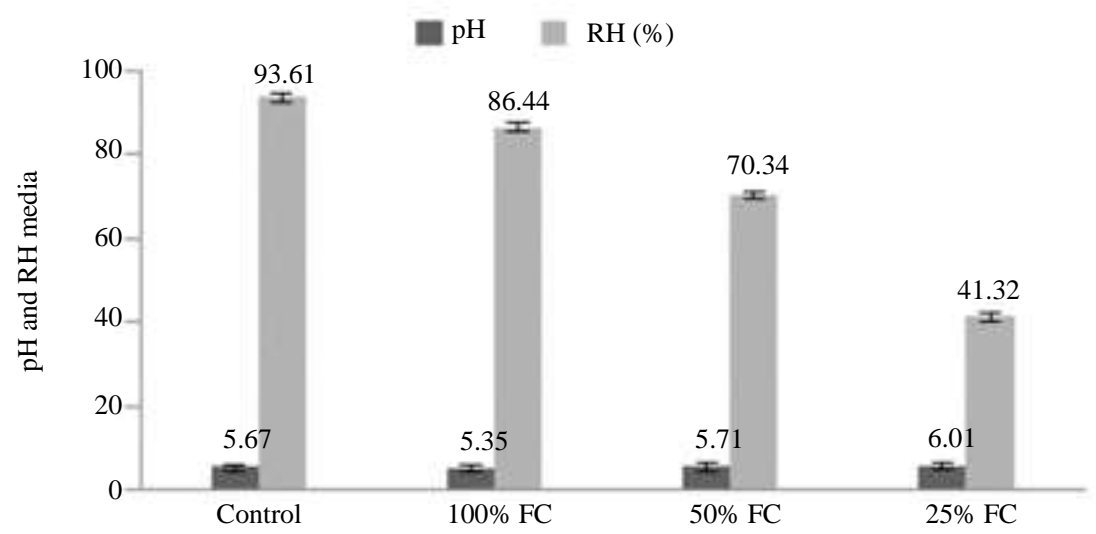

Fig. 3: Relative humidity and $\mathrm{pH}$ of planting media of drought stress treatments Field Capacity (FC) 
Total content of compounds $(\%) \quad$ Insecticide total number

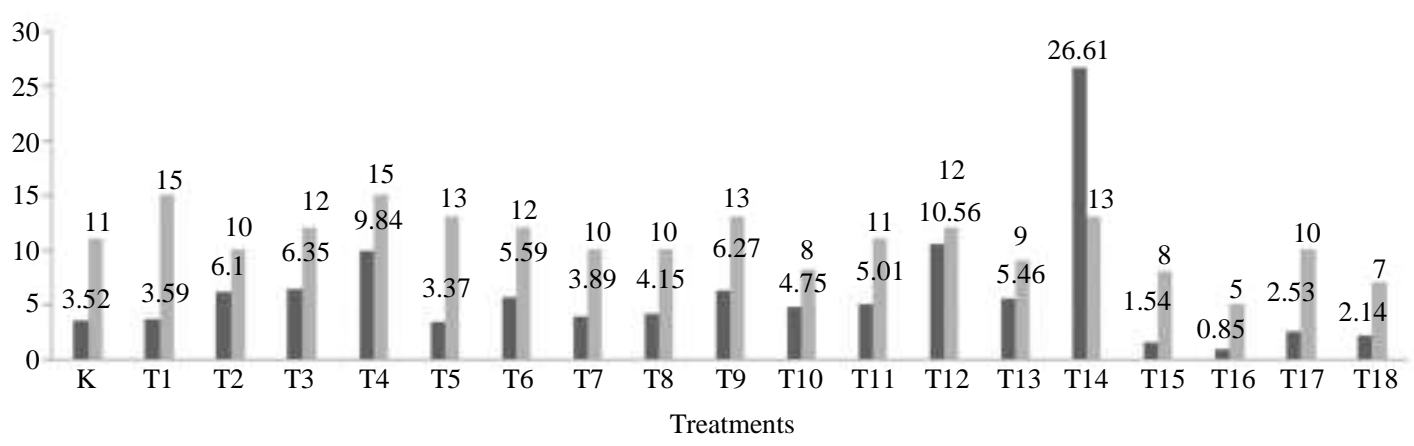

Fig. 4: Total contents and total numbers of insecticide compounds in red betel leaves extract for all combination stress treatments. K: Control, T1: W1F1L1, T2: W1F2L1, T3: W2F1L1, T4: W2F2L1, T5: W3F1L1, T6: W3F2L1, T7: W1F1L2, T8: W1F2L2, T9: W2F1L2, T10: W2F2L2, T11: W3F1L2, T12: W3F2L2, T13: W1F1L3, T14: W1F2L3, T15: W2F1L3, T16: W2F2L3, T17: W3F1L3, T18: W3F2L3

Table 1: Growth of Piper crocatum with combination of drought stress, light treatments and fertilizer application

\begin{tabular}{|c|c|c|c|}
\hline Treatments & Leaves number & Plant height & Soot/root ratio \\
\hline Control & $19.8^{\mathrm{bcde}} \pm 0.26$ & $102.8^{\mathrm{cde}} \pm 1.94$ & $2.34^{\mathrm{b}} \pm 0.35$ \\
\hline W1F1L1 & $20.4^{\mathrm{e}} \pm 0.7$ & $124.6^{\mathrm{de}} \pm 1.55$ & $2.55^{\mathrm{b}} \pm 0.25$ \\
\hline W1F2L1 & $18.25^{\mathrm{abcd}} \pm 1.86$ & $81.4^{b c} \pm 4.47$ & $3.63^{\mathrm{bc}} \pm 2.39$ \\
\hline W2F1L1 & $18.4^{\mathrm{cde}} \pm 0.77$ & $108.8^{\text {cde }} \pm 2.61$ & $2.36^{\mathrm{b}} \pm 0.29$ \\
\hline W2F2L1 & $19.4^{\mathrm{de}} \pm 0.33$ & $105.4^{\text {cde }} \pm 1.17$ & $4.03^{c} \pm 0.43$ \\
\hline W3F1L1 & $15.8^{\text {bcde }} \pm 0.84$ & $83.2^{\mathrm{bc}} \pm 2.74$ & $1.71^{\mathrm{a}} \pm 0.35$ \\
\hline W3F2L1 & $14.4^{\mathrm{abcd}} \pm 1.05$ & $87.6^{b c} \pm 1.39$ & $3.34^{\mathrm{bc}} \pm 0.64$ \\
\hline W1F1L2 & $18.4^{\mathrm{cde}} \pm 0.45$ & $135^{\mathrm{e}} \pm 2.66$ & $4.14^{\mathrm{c}} \pm 0.2$ \\
\hline W1F2L2 & $17.4^{\text {bcde }} \pm 0.42$ & $107^{\mathrm{cde}} \pm 1.62$ & $4.22^{\mathrm{c}} \pm 0.78$ \\
\hline W2F1L2 & $18.4^{\text {cde }} \pm 0.50$ & $100.2^{\mathrm{cd}} \pm 1.28$ & $1.69^{\mathrm{a}} \pm 0.27$ \\
\hline W2F2L2 & $14.2^{\mathrm{abcd}} \pm 1.23$ & $77.4^{\mathrm{abc}} \pm 3.52$ & $3.80^{\mathrm{bc}} \pm 0.68$ \\
\hline W3F1L2 & $14.6^{\mathrm{abcd}} \pm 0.39$ & $73^{\mathrm{abc}} \pm 2.01$ & $1.66^{\mathrm{a}} \pm 0.32$ \\
\hline W3F2L2 & $17.2^{\text {bcde }} \pm 1.24$ & $86.4^{\mathrm{bc}} \pm 3.01$ & $3.08^{b c} \pm 0.3$ \\
\hline W1F1L3 & $15^{\text {abcde }} \pm 0.95$ & $78^{\mathrm{abc}} \pm 2.33$ & $6.28^{\mathrm{d}} \pm 0.92$ \\
\hline W1F2L3 & $15.2^{\mathrm{abcde}} \pm 0.29$ & $85.6^{\mathrm{bc}} \pm 1.34$ & $4.43^{c} \pm 0.64$ \\
\hline W2F1L3 & $13^{\mathrm{abc}} \pm 2.21$ & $54.4^{\mathrm{ab}} \pm 2.56$ & $2.51^{\mathrm{b}} \pm 1.47$ \\
\hline W2F2L3 & $12.4^{\mathrm{ab}} \pm 0.72$ & $64^{\mathrm{ab}} \pm 2.49$ & $3.81^{\mathrm{bc}} \pm 0.48$ \\
\hline W3F1L3 & $9.6^{\mathrm{a} \pm 1.21}$ & $43.8^{\mathrm{a}} \pm 4.08$ & $1.52^{\mathrm{a}} \pm 0.56$ \\
\hline W3F2L3 & $13.8^{\mathrm{abcd}} \pm 1.51$ & $60.8^{\mathrm{ab}} \pm 1.97$ & $3.48^{\mathrm{bc}} \pm 0.76$ \\
\hline
\end{tabular}

Note: The numbers followed by the same letters for each column are not significantly different based on the Duncan Multiple Range Test (DMRT) at the 5\% significance level. W1: Water in 100\% FC, W2: Water in 50\% FC, W3: Water in 25\% FC, F1: Organic fertilizer guano, F2: Inorganic fertilizer NPK, L1: Without shade, L2: Shade net 65\%, L3: Shade net 75\%

Table 2: Nutrient analysis of soil and fertilizers were used in planting media

\begin{tabular}{llccc}
\hline Chemical caracteristics & Unit & Sawitsari soil & Guano fertilizer & NPK fertilizer \\
\hline Sand & $\%$ & 78.0000 & -0.00 & -0.0 \\
Dust & $\%$ & 15.0000 & -0.00 & -0.0 \\
$\mathrm{Clay}$ & $\%$ & 7.0000 & -0.00 & -0.0 \\
$\mathrm{CEC}$ & $\mathrm{cmol}(+) \mathrm{kg}^{-1}$ & 3.5500 & -0.00 & -0.0 \\
$\mathrm{pH}$ & - & 7.0300 & -0.00 & -0.0 \\
$\mathrm{C}$-organic & $\%$ & 1.2800 & 13.23 & -0.0 \\
$\mathrm{~N}$ total & $\%$ & 0.0300 & 0.21 & 16.0 \\
$\mathrm{P}_{2} \mathrm{O} 5$ & $\%$ & 0.0111 & 0.19 & 16.0 \\
$\mathrm{~K} 2 \mathrm{O}$ total & $\%$ & 0.0068 & 0.10 & 16.0 \\
$\mathrm{MgO}$ & $\%$ & -0.0000 & 0.12 & 1.5 \\
$\mathrm{CaO}$ & $\%$ & -0.0000 & 7.19 & 5.0 \\
$\mathrm{Na}$ & $\%$ & -0.0000 & 0.17 & -0.0 \\
$\mathrm{Fe}$ total & $\mathrm{mpm}$ & 120.0000 & 3389.00 & -0.0 \\
$\mathrm{Cu}$ total & $\mathrm{ppm}$ & 2.0000 & 2.00 & -0.0 \\
\hline
\end{tabular}


Table 3: The compounds of the chloroform extract of red betel leaves with the highest preference compound content for each combination of abiotic stress treatment

\begin{tabular}{lllll}
\hline Treatments & Total compounds & Major compounds & Groups & $\%$ Total area \\
\hline Control & 54 & 2-Carene, 2-Acetyl- & Monoterpene & 19.10 \\
W1F1L1 & 64 & 2-Carene, 2-Acetyl- & Monoterpene & 19.29 \\
W1F2L1 & 49 & 2-Carene, 2-Acetyl- & Monoterpene & 43.45 \\
W2F1L1 & 53 & 2-Carene, 2-Acetyl- & Monoterpene & 37.41 \\
W2F2L1 & 67 & 2-Carene, 2-Acetyl- & Propane & 27.94 \\
W3F1L1 & 61 & 2-Hydroxy-Beta-Ionone & Diterpene & 19.04 \\
W3F2L1 & 61 & Phytol & Propane & 19.44 \\
W1F1L2 & 52 & 2-Hydroxy-Beta-Ionone & Propane & 40.45 \\
W1F2L2 & 50 & 2-Hydroxy-Beta-Ionone & Monoterpene & 19.09 \\
W2F1L2 & 58 & 2-Carene, 2-Acetyl- & Phenol & 27.66 \\
W2F2L2 & 45 & 3-Hydroxy-7,8-Dihydro-.Beta.-Ionol & Monoterpene & 36.51 \\
W3F1L2 & 54 & 2-Carene, 2-Acetyl- & Monoterpene & 36.89 \\
W3F2L2 & 46 & 2-Carene, 2-Acetyl- & Phenol & 33.38 \\
W1F1L3 & 44 & 3-Hydroxy-7,8-Dihydro-.Beta-Ionol & 33.96 \\
W1F2L3 & 54 & Delta 3-Carene & Monoterpene & 21.70 \\
W2F1L3 & 39 & 2-Carene, 2-Acetyl- & Monoterpene & 21.61 \\
W2F2L3 & 30 & 2-Carene, 2-Acetyl- & Propane & 51.47 \\
W3F1L3 & 47 & 2-Hydroxy-Beta-Ionone & Propane & 23.88 \\
W3F2L3 & 62 & 2-Hydroxy-Beta-Ionone & 32.16 \\
\hline W & & 2 & & \\
\hline
\end{tabular}

Note: W1: Water in 100\% FC, W2: Water in 50\% FC, W3: Water in 25\% FC, F1: Organic fertilizer guano, F2: Inorganic fertilizer NPK, L1: Without shade, L2: Shade net 65\%, L3: Shade net 75\%

Table 4: Bioactive compounds on red betel leaves chloroform extracts with insecticide potency

\begin{tabular}{|c|c|c|c|}
\hline Groups & Bioactive compounds & Formula & Molecular weight $(\mathrm{g} / \mathrm{mol})$ \\
\hline Terpene & Terpinolene & $\mathrm{C}_{10} \mathrm{H}_{16}$ & 136.230 \\
\hline \multirow[t]{8}{*}{ Monoterpene } & Limonene & $\mathrm{C}_{10} \mathrm{H}_{16}$ & 136.230 \\
\hline & Trans geraniol & $\mathrm{C}_{10} \mathrm{H}_{18} \mathrm{O}$ & 154.250 \\
\hline & Alpha terpineol & $\mathrm{C}_{10} \mathrm{H}_{18} \mathrm{O}$ & 154.250 \\
\hline & Borneol & $\mathrm{C}_{10} \mathrm{H}_{18} \mathrm{O}$ & 154.250 \\
\hline & Rhodinol & $\mathrm{C}_{10} \mathrm{H}_{20} \mathrm{O}$ & 156.260 \\
\hline & Citronella & $\mathrm{C}_{10} \mathrm{H}_{18} \mathrm{O}$ & 154.250 \\
\hline & Linalool & $\mathrm{C}_{10} \mathrm{H}_{18} \mathrm{O}$ & 154.250 \\
\hline & Nerol & $\mathrm{C}_{10} \mathrm{H}_{18} \mathrm{O}$ & 154.250 \\
\hline \multirow[t]{9}{*}{ Sesquiterpene } & Zingiberene & $\mathrm{C}_{15} \mathrm{H}_{24}$ & 204.350 \\
\hline & Beta farnesene & $\mathrm{C}_{15} \mathrm{H}_{24}$ & 204.350 \\
\hline & Beta pinene & $\mathrm{C}_{10} \mathrm{H}_{16}$ & 136.230 \\
\hline & Alpha curcumene & $\mathrm{C}_{15} \mathrm{H}_{22}$ & 202.330 \\
\hline & Beta caryophyllene & $\mathrm{C}_{15} \mathrm{H}_{24}$ & 204.350 \\
\hline & Farnesol & $\mathrm{C}_{15} \mathrm{H}_{26} \mathrm{O}$ & 222.370 \\
\hline & Nerolidol & $\mathrm{C}_{15} \mathrm{H}_{26} \mathrm{O}$ & 222.370 \\
\hline & Gamma cadinene & $\mathrm{C}_{15} \mathrm{H}_{24}$ & 204.350 \\
\hline & Alpha pinene & $\mathrm{C}_{10} \mathrm{H}_{16}$ & 136.230 \\
\hline C-nitro compound & Dinobuton & $\mathrm{C}_{14} \mathrm{H}_{18} \mathrm{~N}_{2} \mathrm{O}_{7}$ & 326.300 \\
\hline \multirow{2}{*}{ Phenylpropene } & Methyl eugenol & $\mathrm{C}_{11} \mathrm{H}_{14} \mathrm{O}_{2}$ & 178.230 \\
\hline & Myristicin & $\mathrm{C}_{11} \mathrm{H}_{12} \mathrm{O}_{3}$ & 192.210 \\
\hline \multirow[t]{3}{*}{ Esther } & 11-Tetradecen-1-ol, acetate, (Z)- & $\mathrm{C}_{16} \mathrm{H}_{30} \mathrm{O}_{2}$ & 254.410 \\
\hline & Benzyl benzoate & $\mathrm{C}_{14} \mathrm{H}_{12} \mathrm{O}_{2}$ & 212.240 \\
\hline & 1,2-Benzenedicarboxylic acid, dibutyl ester & $\mathrm{C}_{16} \mathrm{H}_{22} \mathrm{O}_{4}$ & 278.340 \\
\hline Ether & Phenoxyethene & $\mathrm{C}_{8} \mathrm{H}_{10} \mathrm{O}_{2}$ & 138.166 \\
\hline Ketone & Cis-Jasmone & $\mathrm{C}_{11} \mathrm{H}_{16} \mathrm{O}$ & 164.240 \\
\hline Carbofuran & 3-Hydroxycarbofuran & $\mathrm{C}_{12} \mathrm{H}_{15} \mathrm{NO}_{4}$ & 237.250 \\
\hline \multirow[t]{2}{*}{ Fatty acid } & Oleic acid & $\mathrm{C}_{18} \mathrm{H}_{34} \mathrm{O}_{2}$ & 282.500 \\
\hline & Decanoic acid & $\mathrm{C}_{10} \mathrm{H}_{20} \mathrm{O}_{2}$ & 172.260 \\
\hline Disaccharide & Beta lactose & $\mathrm{C}_{12} \mathrm{H}_{22} \mathrm{O}_{11}$ & 342.300 \\
\hline Organic nitro compound & 2-Nitropropanol & $\mathrm{C}_{3} \mathrm{H}_{7} \mathrm{NO}_{3}$ & 105.090 \\
\hline
\end{tabular}




\section{Discussion}

Growth and development of plant are influenced by internal factors, in the form of genetic factors and plant hormone, as well as external factors, such as microclimatic conditions and growing media that can be adjusted to their needs. Light intensity is an environmental factor that is very important for plant growth and influences other environmental factors. Light plays an important role in the formation of vegetative organs, one of which is the development of leaves. From the results of this study, it can be seen that the higher intensity of irradiation results in a greater number of leaves than those of shaded plants. This is similar to the study of (Zervoudakis et al., 2012) who reported that the highest number of leaves of Sage (Salvia officinalis L.) plants was produced by treatment with full light conditions and the number of leaves was reduced in the shade conditions of 50 and $75 \%$.

According to (Goldsworthy and Fisher, 1992) leaves in shaded conditions will run into faster aging. Leaves is not contributing to produce more net photosynthate, so the rate of vegetative growth is inhibited and the number of leaves in the plant is reduced. This statement is in accordance with the growth of plants in the field. The leaves in shaded plants, especially in the shade net $75 \%$, have a lot of senescence and abscission, so the number of leaves increases. Plants in low light intensity will reduce respiration rate, increase leaf area to expand light absorption and increase photosynthesis rate in each leaf area.

Besides light, water is an important factor which be a limiting factor for plant growth. From the results of the study, the $25 \%$ FC treatment produced the fewest number of leaves compared to other treatments. The number of leaves decreases with increasing stress Table 1. According to (Zokaee-Khosroshahi et al., 2014), drought caused a significant decrease in the number and area of leaves. Decrease in leaf growth is determined by the level and duration of stress in response to minimizing water loss through transpiration.

Red betel has stems that increase in length through the addition of nodes and internodes. According to (Taiz and Zeiger, 2002), plants growing in tightly shaded areas or in low light intensity will grow longer than plants with sufficient light. The levels of auxin in the stems increase during dark conditions and can subsequently cause etiolation in plants. In contrast to (Taiz and Zeiger, 2002; Mapes and $\mathrm{Xu}, 2014$ ), in this study $75 \%$ shade treatment produced the lowest plant height compared to the condition without shade (also control). It can be caused by several factors, for instance stems at high light treatment can continue to grow due to increased gibberellins activity. According to (Sun, 2010), increased cell elongation and cell division occur during stem growth. GA induces transcription genes involved in this process. For example, the expression of several genes encoding Xyloglucan Endo-Transglycosylases (XETs1) and expansion regulated by GA in elongation of rice fields and Arabidopsis.

In this study, plants with high light intensity conditions (treatment without shade) produced better morphological growth compared to treatments with lower light intensity. The number of leaves, stem height and plant biomass in the treatment without shade was higher than the treatment with shade Table 1. The highest light intensity ranged from 37,436 to 40,883 lux in the treatment without shade and control, while the lowest light intensity ranged from 4187 lux Fig. 1. Although according to (Manoi, 2007), red betel plants is like shade plants, have cool air with $60-75 \%$ sunlight and can flourish and thrive in mountainous areas. This shows that the red betel plant has a broad tolerance for light intensity. In this study, light intensity $>40,000$ lux is not considered to be a limiting factor and can't destroy plant growth drastically. High light intensity causes change of temperature and air humidity in the air and planting media. But, it can be tolerated, so the plants still grow well.

The light intensity can affect to the temperature and humidity of the air, it which further affects to the availability of water. Plant response to drought morphologically can be in the form of inhibition of stem growth (Wu and Cosgrove, 2000). In this study, the higher of drought stress made the stem is lower Table 1. It is shown in the treatment group $25 \%$ field capacity. When water deficits occur in the rooting area, an imbalance occurs between plant requirements and water availability. It causes plant metabolism to be inhibited, one of which has an impact on reducing the rate of photosynthesis. When photosynthesis decreases, photosynthate as an energy source for the process of cell division and enlargement is also reduced. Inhibited cell division activity, causing there are not increasing in mass or cell content and cell expansion, so that cells remain smaller (Chaves et al., 2003; Mapegau, 2006). It happened on the stem in the treatment of water stress $25 \%$ that growing shortest based on plant height parameter.

In addition to light and water, the growing media also indirectly plays a role in plant growth. The structure and composition media can be manipulated based on the needs of plant. Based on the results of soil analysis, it is known that the soil media is neutral with a degree of acidity of 7.03. The soil texture is dominated by sand with a Cation Exchange Capacity (CEC) of $3.55 \mathrm{cmol}$ (+) $\mathrm{kg}^{-1}$ Table 2. CEC is a chemical property that is closely related to soil fertility. In this study two kinds of compound fertilizers are used, namely organic guano fertilizer and NPK inorganic fertilizer. Based on the results analysis, one of the micro nutrients found in guano fertilizer is Fe which plays a role in the formation of leaf chlorophyll and high stem growth. Therefore, 
treatment with guano fertilizer results in better stem height and number of leaves compared to NPK fertilizer application. Suwarno and Idris (2007) explained that the application of guano fertilizer can improve soil fertility, increase soil $\mathrm{pH}$, soil CEC, also available N, P, K levels. In this study, the application of organic guano fertilizer has a better influence on the chemical properties of the soil because it can increase $\mathrm{pH}$, although the increase is relatively small. Guano fertilizer contains of $\mathrm{N}, \mathrm{P}, \mathrm{K}$ which very good for supporting growth, stimulating roots, strengthening seedlings. In addition to the elements $\mathrm{N}, \mathrm{P}$ and $\mathrm{K}$, there are macro elements $\mathrm{Mg}$ and $\mathrm{Ca}$ in both types of fertilizers that are useful for plant growth. The availability of macro and micro nutrients in guano fertilizer could increase soil fertility which increase plant growth.

Environmental stress, especially drought stress caused a decrease in root and shoot growth. Plant biomass is directly affected by water availability. Decreased assimilate production in drought conditions causes a decrease in root and shoot biomass. Under drought conditions, plants generally allocate a large proportion of assimilates to root growth rather than shoot. Changes in total biomass determine the ratio of shoot to roots as an indicator of the mechanism of tolerance of plants to stress. Decrease in root and shoot growth causes changes in Root-Shoot ratios (R/S ratio) which show how plants respond to the limitations of the surrounding water (Benjamin and Nielsen, 2004). From Table 1, it is known that shade net $75 \%$ produced the highest $\mathrm{R} / \mathrm{S}$ ratio compared to shade net $65 \%$, without shade and control. The treatment of giving water $100 \%$ FC shows the highest R/S ratio compared to other water stresses. The result of a high $\mathrm{R} / \mathrm{S}$ ratio indicates that the weight of the canopy (leaves and stems) is heavier than the roots.

According to (Wu and Cosgrove, 2000), limited water availability generally decreases $\mathrm{R} / \mathrm{S}$ ratio, because canopy growth is more susceptible to being inhibited by a decrease in water potential. Furthermore (Kondo et al., 2003) stated that the mechanism of plant tolerance to drought is not only through root lengthening, but also by increasing plant root biomass. Changes in the allocation of assimilates are more directed towards root growth than canopy, the aim is to increase access to water absorption. This is consistent with the research conducted, that the ratio of the plant root canopy decreases with increasing environmental stress.

It is known that light is a physical factor that can affect the production of metabolites in plants. High light intensity can stimulate the formation of secondary metabolites, such as gingerol and zingiberene in the $Z$. officinale callus culture (Anasori and Asghari, 2009). In this study, zingiberene (sesquiterpenes) found in red betel leaves extract was potential as an insecticide Table 5. Control and without shade treatments produce Zingiberene for all combinations of abiotic stresses.
While in the treatment of shade net group of 65 and $75 \%$ in combination with others abiotic stress treatments did not produce Zingiberene. This was triggered by the higher light intensity at the planting location of without shade net compared to those of the treatment with the addition of shade net Fig. 1.

The correlation between light and fertilizer application in increasing bioactive compounds in Piper betle plants was also reported by (Muttaleb et al., 2018). The chlorophyll content increased in the treatment under 30 and $50 \%$ shade with $100 \mathrm{~kg} / \mathrm{ha} \mathrm{N}$, while full sunlight with $0 \mathrm{~kg} / \mathrm{ha} \mathrm{N}$ is not suitable for betel plants, because high light intensity causes scorch on the leaves and inhibits growth, accumulation secondary metabolites and activation of antioxidants. Likewise in this study, even without shade the plants can grow well because of the provision of fertilizers and it can increase secondary metabolite products.

The application of abiotic stress has been shown to increase the concentration of secondary metabolites in plants. Abiotic stress, especially drought, decreases growth and gives rise to some morphological, anatomic and biochemical changes in plants, including modification of gene expression which ultimately affects a very large yield decrease. Plants increase drought tolerance by reducing osmotic potential due to accumulation of solutes. This condition allows cell enlargement, plant growth, keeping the stomata open and assimilation of $\mathrm{CO}_{2}$ under water pressure. Many solutes can be used in osmotic adjustment, including inorganic ions such as $\mathrm{Na}^{+}, \mathrm{K}^{+}$and $\mathrm{Cl}^{-}$(Wyn-Jones and Gorhan, 1983), saccharides and amino acids, i.e., proline (Navari-Izzo et al., 1990). As a result, the yield of plant biomass is low despite increasing secondary metabolite levels. However, this research shows that $50 \%$ water capacity in the field, NPK fertilizer and without shade can increase the types and levels of bioactive compounds which are potentially insecticides with better morphology and growth compared to those of other treatments.

The mechanism of the compounds in responding to insect attacks are varied, depending on the type of compound and insect that disturbs plants. Some bioactive compounds produced from red betel leaves extracts such as limonene, myrcene, terpinolene, alpha pinene and beta pinene are neurotoxic to insects (Rattan, 2010; Coats et al., 1991; Dev, 1989). The mechanism of action of eugenol, borneol, citronella and geraniol works in neuromodulatory disorders, octopamine antagonists and membrane disruptors (Dayan et al., 2009; Pino et al., 2013; Isman and Machial, 2006). According to (Felipe et al., 2008; Rattan, 2010), linalool and delta 3-carene play a role in the inhibition of Acetylecholinestrase (AChE). Meanwhile, reported by (Freeman and Beattie, 2008; Khaleel et al., 2018) that alpha terpineol and geraniol can interfere with olfactory responses in insects that cause insects to avoid or even die. 
Secondary metabolites are produced for the defense of living things against stress or attacks from the surrounding environment. Secondary metabolites are not only produced by plants, but can also be produced by animals, especially insects. According to (Beran et al., 2019), there are identical chemical structures of simple monoterpene and sesquiterpene groups, iridoid monoterpenes, cyanogenic glycosides, benzoic acid derivatives, benzoquinone and naphtoquinone that are sometimes found in plants and insects. Potential compounds as an insecticide from red betel leaf extract from this research, i.e., beta caryophyllene, myrcene, beta farnesene and geraniol. They are also found as secondary metabolites in other species of insects and plants (Beran et al., 2019).

In some cases, identical compounds may be produced by plants to interfere with their function in insects. Elsewhere, compounds in plants and insects may have a parallel function, either as a defense or an attractant and the existence of these compounds is a coincidence. The origin of the biosynthesis of these metabolites that occur simultaneously may be very different in insects compared to plants. Plants and insects may have different biosynthetic pathways, but produce the same metabolites, or a sequence of similar intermediates, but different enzymes. Plants produce terpenoids through the MVA and MEP pathways, while the production of terpenoids in insects only through the MAV pathway (Beran et al., 2019).

From this study, it found 32 types of compounds as potential insecticides in red betel leaves extract from different groups, including terpene, monoterpene, sesquiterpene, diterpene and alkaloids. The existence of similarities of compounds produced by plants and insects, may further be explained through knowledge of the ecological role and biosynthetic pathways of secondary metabolites. This has become interesting for the development of agriculture and plantations, especially in eradicating pests. Further studies are needed to determine bioactive compounds in plants and insects that have the potential to increase the ability of repellence and also the resistance of compounds from plants against insect pests.

\section{Conclusion}

Based on the research, it can be concluded that the abiotic stresses combination (waters, lights and fertilizers) could affect the growth of $P$. crocatum, especially the morphology and biomass. The combination treatments of $100 \%$ of FC, guano fertilizer and without shade (W1F1L1) produced the best plant growth. While the combination of $25 \% \mathrm{FC}$, guano and shade net $75 \%$ (W3F1L3) provided the lowest growth yield compared to those of other treatments. The combination of abiotic stresses also increased the types and content of bioactive compounds of $P$. crocatum leaves compared to those of control. The $50 \%$ of FC, NPK fertilizer and without shade (W2F2L1) had the highest potential to increase the types of natural insecticide compounds, while treatment of $100 \% \mathrm{FC}$, NPK fertilizer and shade net $75 \%$ (W1F2L3) resulted in the highest total content of insecticide compounds.

\section{Acknowledgement}

The authors express many thanks to Ministry of Research and Technology, Indonesia for the financial study support provided under the Saintek Funding Scheme and Universitas Gadjah Mada for publication support under the Final Project Recognition Programs (RTA) 2020 of Scheme. Many thanks are also given to Prima W.K. Hutabarat for many support during the research.

\section{Funding Information}

This study was supported by the Saintek Funding Scheme and Universitas Gadjah Mada for publication support under the Final Project Recognition Programs (RTA) 2020 of Scheme.

\section{Author's Contributions}

Intani Quarta Lailaty: Designed research methodology, data collection, data analysis, literature review and manuscript writing, manuscript final reading and approval.

Diah Rachmawati: Designed research methodology, data interpretation, manuscript final reading and approval.

Laurentius Hartanto Nugroho: Conceived idea, designed research methodology, data interpretation, manuscript final reading and approval.

\section{Ethics}

This article is original and contains unpublished material. The corresponding author confirms that all of the other authors have read and approved the manuscript and no ethical issues involved.

\section{References}

Akula, R., \& Ravishankar, G. A. (2011). Influence of abiotic stress signals on secondary metabolites in plants. Plant Signal Behav 6: 1720-1731.

Anasori, P., \& Asghari, G. (2009). Effects of light and differentiation on gingerol and zingiberene production in callus culture of Zingiber officinale Rosc. Research in Pharmaceutical Sciences, 3(1), 59-63.

Benjamin, J. G., \& Nielsen, D. C. (2004). A method to separate plant roots from soil and analyze root surface area. Plant and Soil, 267(1-2), 225-234. 
Beran, F., Köllner, T. G., Gershenzon, J., \& Tholl, D. (2019). Chemical convergence between plants and insects: biosynthetic origins and functions of common secondary metabolites. New Phytologist, 223(1), 52-67.

Bettaieb, I., Zakhama, N., Wannes, W. A., Kchouk, M. E., \& Marzouk, B. (2009). Water deficit effects on Salvia officinalis fatty acids and essential oils composition. Scientia horticulturae, 120(2), 271-275.

Chaves, M. M., Maroco, J. P., \& Pereira, J. S. (2003). Understanding plant responses to drought-from genes to the whole plant. Functional plant biology, 30(3), 239-264.

Coats, J. R., Karr, L. L., \& Drewes, C. D. (1991). Toxicity and neurotoxic effects of monoterpenoids: in insects and earthworms.

Dayan, F. E., Cantrell, C. L., \& Duke, S. O. (2009). Natural products in crop protection. Bioorganic \& medicinal chemistry, 17(12), 4022-4034.

Dev, S. (1989). Terpenoids. In Natural products of woody plants (pp. 691-807). Springer, Berlin, Heidelberg.

Felipe, C. F. B., Fonsecirc, K. S., Bezerra, J. N. S., de Franccedil, M. M., \& de Barros Viana, G. S. (2008). Alterations in behavior and memory induced by the essential oil of Zingiber officinale Roscoe (ginger) in mice are cholinergic-dependent. Journal of Medicinal Plants Research, 2(7), 163-170.

Freeman, B. C., \& Beattie, G. A. (2008). An overview of plant defenses against pathogens and herbivores. The Plant Health Instructor.

Goldsworthy, P. R., \& Fisher, N. M. (1992). Fisiologi Tanaman Budidaya Tropik. Tohari (Penerjemah).

Isman, M. B., \& Machial, C. M. (2006). Pesticides based on plant essential oils: from traditional practice to commercialization. Advances in phytomedicine, 3, 29-44.

Khaleel, C., Tabanca, N., \& Buchbauer, G. (2018). $\alpha-$ Terpineol, a natural monoterpene: A review of its biological properties. Open Chemistry, 16(1), 349-361.

Kondo, M., Pablico, P. P., Aragones, D. V., Agbisit, R., Abe, J., Morita, S., \& Courtois, B. (2003). Genotypic and environmental variations in root morphology in rice genotypes under upland field conditions. In Roots: The Dynamic Interface between Plants and the Earth (pp. 189-200). Springer, Dordrecht.

Laise, R. A., Ahmad, M., \& Tangge, L. (2017). Respon pertumbuhan tanaman cabai (Capsicum frutescens $\mathrm{L}$.) terhadap cekaman air untuk pemanfaatannya sebagai media pembelajaran. e-JIP BIOL. 5(1): 109-118. http://jurnal.untad.ac.id/jurnal/index.php/EBiol/articl e/view/9373

Litsinger, J. A. (2009). When is a rice insect a pest: yield loss and the green revolution. In Integrated pest management: innovation-development process (pp. 391-498). Springer, Dordrecht.
Litsinger, J. A., Barrion, A. T., Canapi, B. L., Libetario, E. M., Pantua, P. C., Cruz, C. G., ... \& Macatula, R. F. (2015). Leptocorisa rice seed bugs (Hemiptera: Alydidae) in Asia: a review. Philippine Entomologist, 29(1), 1-103.

Manoi, F. (2007). Sirih merah sebagai tanaman obat multifungsi. Warta Puslitbangbun, 13(2).

Mapegau, M. (2006). Pengaruh Cekaman Air terhadap Pertumbuhan dan Hasil Tanaman Kedelai (Glycine max L. Merr). Jurnal Ilmiah Pertanian Kultura, 41(1).

Mapes, C., \& Xu, Y. (2014). Photosynthesis, vegetative habit and culinary properties of sage (Salvia officinalis) in response to low-light conditions. Canadian journal of plant science, 94(5), 881-889.

Mazid, M., Khan, T. A., \& Mohammad, F. (2011). Effect of abiotic stress on synthesis of secondary plant products: a critical review. Agricultural Reviews, 32(3), 172-182.

Mølmann, J. A., Steindal, A. L., Bengtsson, G. B., Seljåsen, R., Lea, P., Skaret, J., \& Johansen, T. J. (2015). Effects of temperature and photoperiod on sensory quality and contents of glucosinolates, flavonols and vitamin $\mathrm{C}$ in broccoli florets. Food chemistry, 172, 47-55.

Muttaleb, Q. A., Abdullah, T. L., Hassan, S. A., Rashid, A. A., Taheri, S., Ahmend, O. A., \& Abdulameer, D. A. (2018). The Role of Shade and Nitrogen on Physiological Traits and Secondary Metabolites of Piper betle L. Journal of Horticulture, 5(2), 1-8.

Navari-Izzo, F., Quartacci, M. F., \& Izzo, R. (1990). Waterstress induced changes in protein and free amino acids in field grown maize and sunflower. Plant Physiology and Biochemistry (Paris), 28(4), 531-537.

Nowak, M., Kleinwaechter, M., Manderscheid, R., Weigel, H. J., \& Selmar, D. (2010). Drought stress increases the accumulation of monoterpenes in sage (Salvia officinalis), an effect that is compensated by elevated carbon dioxide concentration. Journal of Applied Botany and Food Quality, 83(2), 133-136.

Nugroho, L. H., Pratiwi, R., Soesilohadi, R. H., Subin, E. R., Wahyuni, S., Hartini, Y. S., \& Lailaty, I. Q. (2020). Repellent Activity of Piper spp. Leaves Extracts on Rice Ear Bugs (Leptocorisa oratorius Fabricius) and the Characters of Its Volatile Compounds. Annual Research \& Review in Biology, 34-45.

Parfati, N., \& Windono, T. (2016). Sirih merah (Piper crocatum Ruiz \& Pav.) kajian pustaka aspek botani, kandungan kimia, dan aktivitas farmakologi. Media Pharinaceutica lndonesiana, 1(2), 106-115.

Pino, O., Sánchez, Y., \& Rojas, M. M. (2013). Plant secondary metabolites as an alternative in pest management. I: Background, research approaches and trends. Revista de Protección Vegetal, 28(2), 81.

Rattan, R. S. (2010). Mechanism of action of insecticidal secondary metabolites of plant origin. Crop protection, 29(9), 913-920. 
Salim, M., Yahya, Y., Sitorus, H., Ni'mah, T., \& Marini, M. (2019). Hubungan kandungan hara tanah dengan produksi senyawa metabolit sekunder pada tanaman duku (Lansium domesticum Corr var Duku) dan potensinya sebagai larvasida.

Seigler, D. S. (1998). Sesquiterpenes. In Plant Secondary Metabolism (pp. 367-397). Springer, Boston, MA.

Sumarwoto, Susilawati, \& Adhityanti, Y. (2008). Uji sirih merah (Piper crocatum Ruiz and Pav.) pada berbagai intensitas sinar matahari dan media tanam. Jurnal Pertanian Mapeta, 11 (1): 1-8

Sun, T. P. (2010). Gibberellin signal transduction in stem elongation \& leaf growth. In Plant hormones (pp. 308-328). Springer, Dordrecht.

Suwarno \& Idris, K. 2007. Potensi dan kemungkinan penggunaan guano secara langsung sebagai pupuk di indonesia. Jurnal Tanah dan Lingkungan, 9 (1): 37-43.

Taiz, L., \& Zeiger, E. (2002). Plant Physiology 3rd ed Sinauer Associates Inc Publishers. Sunderland, MA 690p.

Wu, Y., \& Cosgrove, D. J. (2000). Adaptation of roots to low water potentials by changes in cell wall extensibility and cell wall proteins. Journal of Experimental Botany, 51(350), 1543-1553.
Wyn-Jones, R. G., \& Gorhan, J. (1983). Osmoregulation. In: Lange, H., et al., (Eds.), Physiological Plant Ecology. III. Responses to chemical and Biological Envirnment. (Encylopedia of Plant Physiology, New Series, Vol 12C) Springer-Verlag, BerlinHeidelberg-New York, pp. 35 https://www.springer.com/gp/book/9783642681554

Yeo, Y. L., Chia, Y. Y., Lee, C. H., Sow, H. S., \& Yap, W. S. (2014). Effectiveness of maceration periods with different extraction solvents on in-vitro antimicrobial activity from fruit of momordica charantia L. Journal of Applied Pharmaceutical Science, 4(10), 16-23.

Yudistira, T., Harahap, A., \& Batubara, L. R. (2018). Effect of guano fosfat organic fertilizer and npk jago tani fertilizer application on growht of pepper shrub seedling (Piper nigrum L.). Bernas, 14(1), 119-125.

Zervoudakis, G., Salahas, G., Kaspiris, G., \& Konstantopoulou, E. (2012). Influence of light intensity on growth and physiological characteristics of common sage (Salvia officinalis L.). Brazilian archives of biology and technology, 55(1), 89-95.

Zokaee-Khosroshahi, M., Esna-Ashari, M., Ershadi, A., \& Imani, A. (2014). Morphological changes in response to drought stress 